\title{
REFLECTION
}

\section{Gazing at the Future}

Steve M. Blevins, MD

Health Sciences Center, University of Oklahoma, Oklahoma City, Oklahoma

Conflicts of interest: none reported.

\section{CORRESPONDING AUTHOR}

Steve M. Blevins, MD

University of Oklahoma

920 Stanton L. Young Blvd WP 1160

Oklahoma City, OK 73104

Steve-Blevins@ouhsc.edu

\begin{abstract}
Jerry Bryant has advanced Parkinson's disease. Ten years ago, he became my patient. Last spring, he became my solace and inspiration.
\end{abstract}

Ann Fam Med 2009;7:463-464. DOI:10.1370/afm.1000.

$\int$

erry never complains. He is 58 years old and inseparable from his wife, Betty. They irrepressibly cheerful-synesthetic, in fact: when one laughs, the other cheers. As teenagers, they fell in love, and in love they remain. They are masters of resilience-emotionally, that is. Physically, Jerry has struggled, but he is better now because of Betty and ready for a 40th "honeymoon." Soon they will be sunbathing in the Caribbean.

I am delighted to see Jerry and Betty at the end of a long day. Jerry is sitting on the examination table, quiet and motionless. He has lost a few pounds but is still plump. His thin, straw hair is neatly cut. His brown eyes are magnified by thick lenses. He looks awkward in an undersized gown. Staring ahead, he seems transfixed by the empty wall before him. Betty stands by him, her arm draped casually around his shoulder.

"Good afternoon," I say.

"Hi, Dr Blevins," they reply.

I smile at Betty and turn to Jerry.

"So, Jerry, where are you taking your lovely bride?"

He grins and glances at his wife. "Anguilla," he mumbles.

"Really?" I ask. "Why Anguilla?"

His face brightens; his eyes sparkle. He begins to rhapsodize on the charms of Anguilla, or so I suppose, for I cannot understand a word he is saying. Still, his enthusiasm is unmistakable.

Betty understands every word. She translates: "Anguilla has sun-

drenched beaches, pristine waters, and midnight barbecue." Then realizing that she sounds like a brochure, she laughs and adds, "Jerry's dreaming of the barbecue. I'm dreaming of the beach."

Jerry is amused, which brings joy to his wife.

"Are you healthy enough to go, Jerry?" I ask teasingly.

"You bet!" he mumbles.

I look at Betty, as if needing confirmation. "Is he telling the truth?"

"He certainly is," she replies. "He's having a little trouble with balance, but he walks every day."

Jerry's tremors began when he was 30 years old. Two years later, Parkinson's disease was diagnosed. His condition has progressed slowly. Last year, he received a brain stimulator, which he loves. His tremors are gone now, but his voice is muffled and his limbs are stiff. He cannot write, but he can walk alone, although he prefers to hold Betty's hand.

Pulling out my stethoscope, I check his blood pressure and examine him. As always, I regale him with stories of my weekend adventures. He enjoys my stories, even the silly ones.

"Well, everything checks out," I conclude. "You're good to go! Have a safe trip and don't eat too much."

I leave the room smiling. Jerry and Betty have a magical effect on me. 
Their joy is contagious.

Returning to my office, I sit at my desk and dictate a few notes. After completing my work, I reach into the top drawer, pull out a bottle, and remove a large orange pill. With a swig of water, I swallow the day's last dose of levodopa.

Leaning back in my chair, I reflect on the events of last spring: the first time my hand fumbled while combing my hair, the morning I first used 2 hands to brush my teeth, the afternoon I began to have trouble writing.

I was 45 years old and I was convinced that I had injured my arm at the gym. When my condition did not improve, I arranged to see my doctor.

I remember his kindness. He listened carefully to my story and tested my arm in a dozen ways. His examination ended with an apocalyptic request: he asked me to tap my feet. The request seemed superfluous, because I could run and swim without difficulty. I acquiesced, and to my astonishment, my right foot faltered.

My journey into the surreal may have lasted only a second. I heard children giggling in a distant examination room and smelled alcohol from the adjacent sink. I noticed a cricket in the overhead light and saw patches of light and dark on my doctor's white coat.

My disease was nameless, but I knew the essentials: It was central, neurological, and surely progressive. When the name Parkinson's was introduced, the mystery had already lost its sting.

For several days I was too distracted to work. I barely listened to my patients and wrote the wrong date on prescriptions. Impatiently I waited for the weekend with its promise of isolation. When Friday arrived, I was too preoccupied to notice Jerry's arrival.

Dazed, I entered the room and looked at him. He was perched comfortably on the examination table. Betty stood quietly beside him. Perhaps we conversed. One memory remains: As I approached him with my stethoscope, we looked at each other-he with his Parkinsonian stare; I with the gaze of abject fear. I imagined his decades-long struggle: the frozen movements, the shaking, the distorted voice, the stimulator. He was a crystal ball through which I saw my own bleak future. I wondered when my movements would congeal, when my voice would fade, when....

Jerry's smile interrupted my reverie. I began to examine him. I checked his blood pressure and listened to his heart, but I could only think of his silent immobility.

As I listened to his lungs, he began to snicker. Sometimes Jerry behaved oddly. I usually delighted in his eccentricity, but not today. I was in no mood for his antics. From the corner of my eye I could see Betty's nervous expression. Raising her finger to her mouth, she encouraged her husband to shush. But Jerry kept smiling.

"What is it, Jerry?" I asked.
He turned to Betty and mumbled something, but perturbed, she ignored his childish behavior. Jerry waited for the translation, knowing that Betty would eventually give in. Soon her expression softened, and with rolling eyes, she said, "Dr Blevins, Jerry wants you to know that you have shaving cream in your ear."

That evening I sat on my bed and looked out the window. The park was lovely with its vernal backdrop of blue skies and green fields. An old man was riding a bicycle. A mother was pushing a baby carriage. Children were racing on their skateboards.

I thought about Jerry. His happiness defied nature; it was perennial. For 10 years I had reveled in his good humor, though now it seemed eerie and discordant. My despair, of course, seemed justified-but why? My limitations were few and mild. Jerry, by contrast, was almost mute, but seemed oblivious to his condition. Was he unrealistic? Was I?

Spring drifted into summer, and Jerry returned to clinic with his usual cheer. During his visit, I glanced at him repeatedly, hoping to glimpse the future. His condition had not changed: His eyes were unblinking; his pose was statuesque. But the crystal ball, which penetrated deeper, revealed a future less foreboding. His suffering, though still extant, was subsumed by a graceful serenity. Perhaps I had misread the future last spring. Perhaps time had sharpened my foresight.

I thought about Jerry throughout the summer.

Then one day Betty called to say that Jerry wanted to go to the Caribbean. They had never been there, and with their 40th anniversary approaching, they were determined to go. Jerry needed a "preflight clearance" and had scheduled an appointment to see me.

And so he arrives today, fit to travel. His blood pressure is normal. His neurological condition, though advanced, is safely quarantined from his happy life. He has heard the Caribbean's call and will pursue its promise of sunny beaches and midnight barbecue.

Daylight has passed along with my daydream. The clinic is empty. I put on my coat and turn out the light. For a moment I imagine Jerry in a swimsuit, covered head-to-toe in sunscreen, mumbling and fumbling on the beach. Maybe it is time to stop thinking about the future. After all, there is no crystal ball, just a mirror reflecting the obvious: Jerry is happy.

And I am happy thinking of Jerry dreaming of Anguilla.

To read or post commentaries in response to this article, see it online at http://www.annfammed.org/cgi/content/full/7/5/463.

Key words: Physician-patient relations; Parkinson's disease

Submitted December 20, 2008; submitted, revised, February 19, 2009; accepted March 2, 2009. 